\title{
Perbaikan Proses Bisnis Pembuatan Laporan Produksi Harian untuk Memperpendek Lead Time pada Perusahaan Manufaktur Mobil
}

\author{
Anastasia L. Maukar ${ }^{1}$, Nathalia Tjan ${ }^{1}$, Fitri Marisa ${ }^{2}$, Anik Vega Vitianingsih ${ }^{3}$, Erri Wahyu \\ Puspitarini $^{4}$ \\ 1) Faculty of Engineering, Industrial Engineering Department, President University \\ 2) Teknik Informatika, Universitas Widyagama, Malang \\ 3)Teknik Informatika, Universitas Dr. Soetomo, Surabaya \\ 4) Teknik Informatika, STMIK Yadika Bangil, Pasuruan \\ Email: almaukar@president.ac.id, nathalia.tjhan@gmail.com, vega@unitomo.ac.id, \\ fitrimarisa@widyagama.ac.id, www.erri@stmikyadika
}

\begin{abstract}
This research was conducted at a four-wheeled vehicle manufacturing company located in Jakarta. The average lead time for making the Plant 2 Daily Production Report is currently around 12 minutes. With the long reporting time, this process is considered less efficient. In this research, business process improvement will be carried out by identifying non-value-added activities and using business process improvement methodology. In improving the reporting process, Excel Macros will be used. After the implementation of business process improvements, the average time for making Daily Production Reports is reduced to 4 minutes or there is a time saving of $67 \%$.
\end{abstract}

Keywords: lead time, non value-added activity, business process improvement methodology, production report, macro excel.

\begin{abstract}
ABSTRAK
Penelitian ini dilakukan pada perusahaan manufakur kendaraan roda empat yang berlokasi di Jakarta. Rata-rata lead time pembuatan Laporan Produksi Harian plant 2 saat ini sekitar 12 menit. Dengan lamanya waktu pembuatan laporan, maka proses ini dianggap kurang efisien. Dalam penelitian ini akan dilakukan perbaikan bisnis proses dengan cara mengidentifikasikan aktivitas-aktivitas yang tidak memiliki nilai tambah (non value-added activity) dan menggunakan business process improvement methodology. Dalam perbaikan proses pembuatan laporan akan digunakan Macro Excel. Setelah dimplementasi perbaikan proses bisnis maka rata-rata waktu pembuatan Laporan Produksi Harian berkurang menjadi 4 menit atau terjadi penghematan waktu sebesar $67 \%$.
\end{abstract}

Kata kunci: lead time, non value-added activity, business process improvement methodology, laporan produksi, macro excel.

\section{Pendahuluan}

Proses biasanya didefiniskan sebagai serangkaian kegiatan yang harus diselesaikan untuk mencapai sesuatu, atau rangkaian peristiwa atau kejadian yang menghasilkan sesuatu yang dibutuhkan. Proses membutuhkan input dan menghasilkan output. Output ini akan dikonfirmasikan dan bisa digunakan untuk proses berikutnya (Bellgran \& Säfsten, 2010). Salah satu tujuan perusahaan adalah membuat waktu pekerjaan pemrosesan sesingkat mungkin. Waktu pemrosesan pekerjaan yang cukup singkat dapat mempersingkat waktu tunggu. Hal ini disebabkan tenaga kerja dapat memproses pekerjaan-pekerjaan berikutnya atau lainnya lebih awal sehingga pekerjaan-pekerjaan berikutnya itu tidak mengantri terlalu lama.

Selain itu lead time yang singkat juga bermanfaat bagi perusahaan dan juga merupakan suatu ukuran efisiensi. Jika pemrosesan pekerjaan dapat menghemat waktu, maka dapat memperpendek lead time( Metzinger \& Latif, 2003). Lead time yang jauh lebih pendek dapat menghemat biaya, dalam hal ini adalah biaya lembur, karena jam lembur dapat dikurangi. Ini berarti bahwa biaya lembur untuk tenaga kerja berkurang yang sangat berguna bagi perusahaan karena anggaran lembur tidak murah. Apalagi itu berdampak 
besar ketika pekerjaan itu diproses secara teratur. Pekerjaan itu juga akan diproses lebih cepat oleh proses berikutnya yang mempengaruhi proses terakhir yang merupakan pelanggan. Akhirnya, kebutuhan dan kepuasan pelanggan dapat terpenuhi. Semua itu adalah manfaat dari pengurangan lead time. Manfaat dari delivery lead time yang lebih pendek hanya dianggap menguntungkan jika dapat dicapai tanpa pengorbanan pada aspek lain seperti, kualitas dan throughput(Srinivasan K A \& Shrehari J, 2017) .

Pembuatan Laporan Produksi Harian adalah salah satu kegiatan atau aktivitas penting karena laporan tersebut akan dikirim ke Pusat Toyota (Jepang), kantor pusat (Asia Pasifik), dan semua divisi terkait di pabrik Indonesia. Laporan tersebut mencakup data pencapaian produksi, efisiensi, lembur, dan masalah harian produksi. Laporan dibuat dengan mengubah format dari pabrik di Karawang menjadi format yang dibutuhkan perusahaan. Untuk membuat Laporan Produksi Harian, diperlukan file yang dikembangkan di Microsoft Excel. Mengenai fungsi pekerjaan yang menggantikan format dari sisi pabrik ke dalam format yang diperlukan. Kegiatan ini membutuhkan beberapa Langkah proses dan ada beberapa langkah adalah kegiatan yang tidak bernilai tambah. Mengacu pada tujuan perusahaan yaitu memproses suatu pekerjaan secara efektif dan efisien, aktivitas yang tidak bernilai tambah ini harus dihilangkan (Hossain, Bissenova, \& Kim, 2019). Contoh aktivitas yang tidak memiliki nilai tambah (non-value added activity) dalam penggunaan Ms. Excel seperti menyalin data dari satu sel ke dalam sel lain.

Tujuan utama penelitian ini adalah untuk memperpendek proses lead time pembuatan Laporan Produksi Harian. Lead time dalam hal ini adalah saat laporan produksi diterima dari pabrik sampai selesai diolah menjadi Lapran Produksi Harian. Untuk memperpendek waktu pembuatan laporan, maka akan dilakukan perbaikan proses bisnis dengan mengidentifikasikan aktivitas-aktivitas yang tidak memiliki nilai tambah (Rashid \& Ahmad, 2013).

\section{Metode}

Observasi dilakukan di di bagian Perencanaan dan Pengendalian dari car manufacturing company, yang berlokasi di Jakarta. Saat ini, bagian ini memiliki pekerjaan perencanaan kendaraan berfokus pada produk inhouse yang sebagian besar informasinya berasal dari Pabrik yang berlokasi di Karawang. Bagian ini bertanggung jawab untuk merencanakan kuantitas produksi dan lembur karyawan, dan lain-lainya.

Dalam penelitian ini digunakan metodologi untuk melakukan perbaikan proses bisnis. Metodologi perbaikan proses bisnis terdiri dari tujuh tahapan, yaitu: memahami proses saat ini, memodelkan proses saat ini, memvalidasi proses saat ini, menganalisis dan mengevaluasi proses saat ini, redesign proses saat ini, mengevaluasi hasil redesigned proses, dam mengimplementasikan redesigned proses (Aburub, 2014). Adapun Langkah-langkah perbaikan proses bisnis untuk memperpendek lead time dapat dilihat pada Gambar 1.

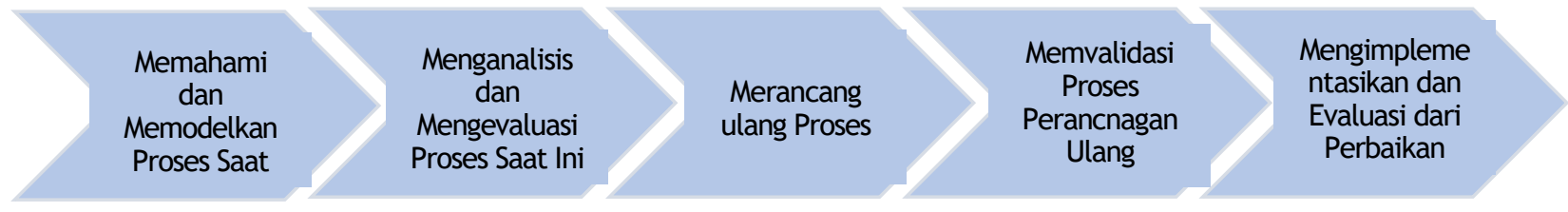

Gambar 1. Diagram Alir Penelitian

Sebagai langkah awal dalam perbaikan proses bisnis, adalah memahami proses saat ini dengan melakukan interview dengan departemen produksi dan bagian yang terkait serta melakukan observasi di lapangan. Dari tahapan ini didapatkan bahwa dalam setahun terakhir, pembuatan laporan belum diproses secara efisien dan efektif. Pekerjaan pembuatan laporan adalah pekerjaan sehari-hari yang harus dilakukan. Pembuatan laporan dilakukan menggunakan Microsoft Excel. Proses pengumpulan data dilakukan pada bagian Perencanaan Produksi. Data yang terkumpul berupa laporan produksi kendaraan harian.

Setelah semua data terkumpul, penelitian dimulai dari mempelajari Laporan Produksi Harian, pentingnya dan fungsinya. Selanjutnya dilakukan analisis dan evaluasi proses saat ini dengan menggambarkan diagram alir dari proses bisnis pembuatan laporan untuk kondisi saat ini. Pembuata diagram alir (flowchart) merupakan salah satu kegiatan awal dalam perbaikan proses bisnis. Diagram alir proses, sangat berguna untuk pemahaman yang jelas tentang proses, membantu mengidentifikasi operasi yang tidak bernilai tambah, memfasilitasi kerja tim dan komunikasi, memastikan semua orang yang terlibat dalam perbaikan proses bisnis memiliki pemahaman yang sama (Halseth, 2018). Flowchart dapat menunjukkan redundansi, 
penundaan, jalan buntu, dan jalur tidak langsung yang jarang diperhatikan atau bahkan diabaikan. Diagram alir merupakan salah satu alat/tool untuk yang dapat digunakan dalam proyek perbaikan proses dengan memahami arus informasi, orang, dan sumber daya (Prasad, Brian Neal, 2014). Adapun lambang atau simbol dari diagram alir/flowchart beserta artinya dapat dilihat pada Tabel 1.

Tabel 1. Simbol dan Arti dari Diagram Alir

\begin{tabular}{|c|c|c|}
\hline Simbol & Arti & Comtoh \\
\hline & Aktivitas & $\begin{array}{l}\text { Data diinput } \\
\text { PO disetujui }\end{array}$ \\
\hline & Keputusan & $\begin{array}{l}\text { Ya/Tidak } \\
\text { Setuju/Tidak } \\
\text { Pass/Fail }\end{array}$ \\
\hline & Dokumen & $\begin{array}{l}\text { Purchase Requisition } \\
\text { Klaim Biaya } \\
\text { Transaction Record }\end{array}$ \\
\hline & Input/Output & Input data \\
\hline & Start/Stop & Dari/Ke \\
\hline & Konektor & $\begin{array}{l}\text { Go To ke bagian lain dari } \\
\text { flowchart }\end{array}$ \\
\hline & Panah & $\begin{array}{l}\text { Menunjukkan arah dari } \\
\text { proses menuju ke simbol } \\
\text { atau proses lainnya }\end{array}$ \\
\hline & Delay/Penundaan & $\begin{array}{l}\text { Menunggu untuk diproses } \\
\text { Laporan menunggu di } \\
\text { meja }\end{array}$ \\
\hline
\end{tabular}

Kemudian, data tentang rencana perbaikan yang akan dilakukan yang berkaitan dengan perangkat lunak/software. Rencana perbaikan dilakukan dengan berdiskusi dengan ahlinya. Setelah dilakukan perbaikan dan dirancang ulang proses bisnisnya, maka akan digambarkan ulang diagram alir proses setelah perbaikan. Kemudian dilakukan perhitungan rata-rata dari waktu pemrosesan dihitung berdasarkan kondisi saat ini dan kemudian menganalisisnya. Selanjutnya, merancang perbaikan dengan memperbaiki proses bisnis dan mengembangkan Macro-Excel. Ini menggunakan Visual Basic yang kodenya harus direfleksikan dengan rumus yang tepat agar sistem di Excel, tidak diperlukan instalasi. Hasil akhirnya adalah berupa pengembangan perangkat lunak, user manual, software documentation serta dilakukan perbandingan sistem saat ini dan sistem yang diusulkan.

\section{Hasil dan Pembahasan}

Laporan Produksi Harian adalah laporan yang terdiri dari produksi harian yang terkait dari Plant 1 dan Plant 2 yang berisi pencapaian dan permasalahan (jika ada). Dalam laporan ini, laporan pabrik 2 akan digunakan untuk menganalisis untuk perbaikan.Permasalahan yang dilaporkan biasanya berkaitan dengan kualitas, peralatan, pasokan, body full, kekurangan body, atau lainnya. Permasalahan tersebut menciptakan line stop yang berdampak pada efisiensi, kuantitas, dan lembur. Laporan ini merupakan informasi yang dibutuhkan untuk melakukan analisis perbandingan antara kondisi aktual dan perencanaan.

Pertama, laporan produksi dikirim dari pabrik ke Departemen Produksi dan Kontrol atau Production and Control Department (PCD). Format Laporan Karawang dapat dilihat pada Gambar 2. Kemudian, PCD memproses laporan tersebut dengan menggunakan data dari plant sebagai sumber dan membuat 'Laporan Produksi Harian' dengan format PCD seperti yang ditunjukkan Gambar 3 satu hari kemudian setelah hari produksi. Setelah selesai, laporan akhirnya dikirimkan ke Headquater Asia Pasifik dan Headquater Jepang, dan beberapa departemen terkait yang membutuhkan informasi produksi.

Laporan Produksi Harian atau Daily Production Report (DPR) diformat dalam Microsoft Excel. Proses pembuatan laporan perlu diperbaiki karena ada beberapa tahapan yang tidak memiliki nilai tambah. Data diinput (format DPR) dan diambil (format Karawang) di tempat yang sama. Apalagi Laporan Produksi Harian atau DPR adalah pekerjaan tetap dan rutin yang diproses setiap hari selama produksi berjalan terus-menerus. Oleh karena itu, perlu dilakukan perbaikan dalam pengurangan waktu pemrosesan Laporan Produksi Harian. 


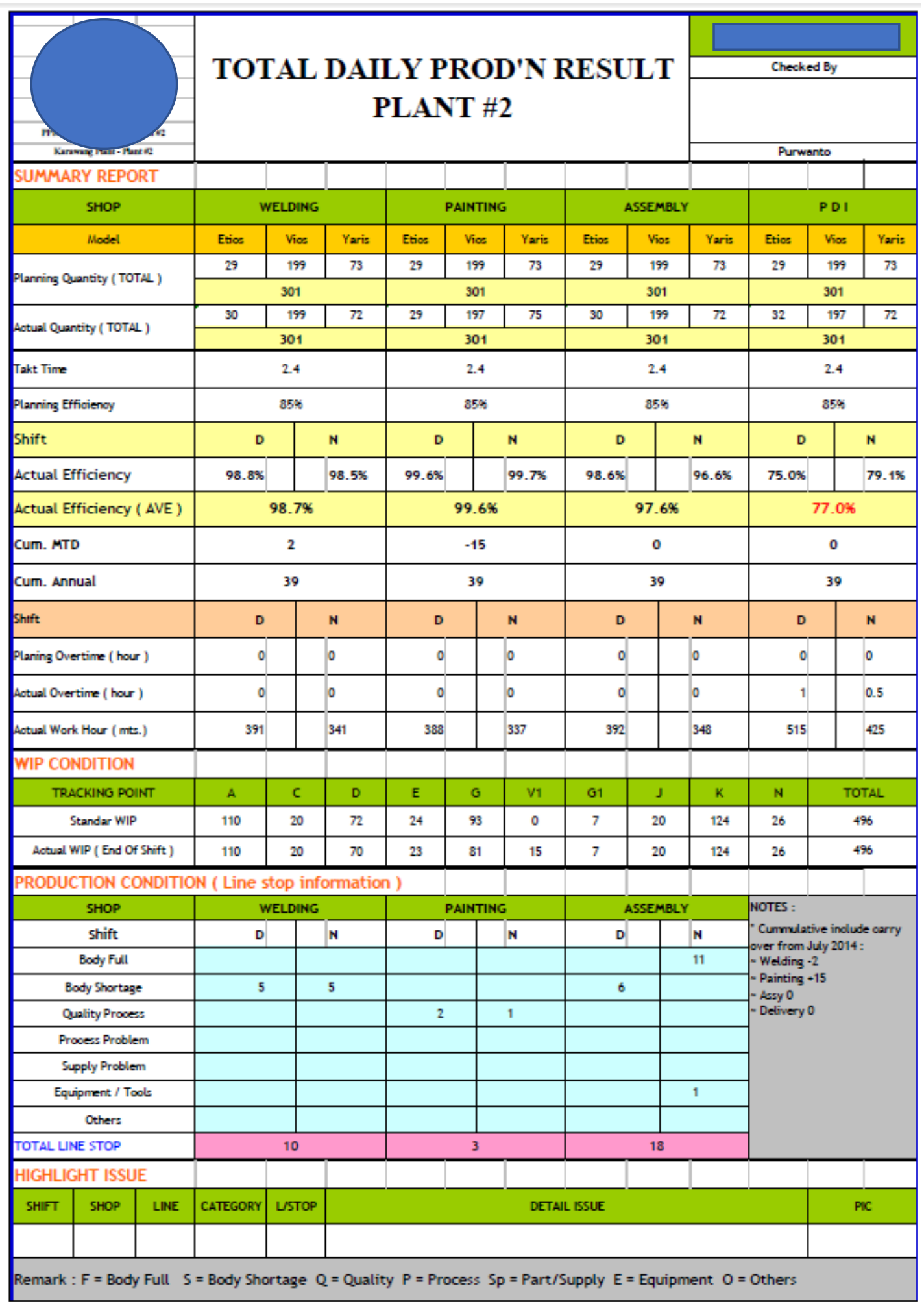

Gambar 2. Contoh Laporan Produksi Harian dari Plant 2 


\begin{tabular}{|c|c|c|c|c|c|c|c|c|}
\hline \multirow{2}{*}{\multicolumn{9}{|c|}{$\begin{array}{l}\text { PT TOYOTA MOTOR MANUFACTURING INDONESIA } \\
\text { PRODUCTON CONIROL DN. } \\
\text { SUMMARY PROD. REPORT KARAWANG PLANT PLANT \#2 (EFC-B \& } \\
\text { Producfion as of: } \quad \text { 11-Aug-14 }\end{array}$}} \\
\hline & & & & & & & & \\
\hline & & \multicolumn{3}{|c|}{ DAILY } & \multicolumn{3}{|c|}{ MONTTLY (MTD) } & \multirow{2}{*}{$\begin{array}{l}\text { Last month } \\
\text { Blc. (MTD) }\end{array}$} \\
\hline & & PLAN & ACT & $+1-$ & PLAN & ACT & $+1-$ & \\
\hline \multirow{4}{*}{ DELUVERY } & EFC-B & 29 & 32 & 3 & 140 & 141 & 1 & -1 \\
\hline & EFC-C SD & 199 & 197 & -2 & 947 & 961 & 4 & 0 \\
\hline & EFCCC $+B$ & 73 & 72 & -1 & 346 & 341 & 5 & -9 \\
\hline & TOTAL & 301 & 301 & 0 & 1433 & 1433 & 0 & 0 \\
\hline
\end{tabular}

ReportDate: $\quad$ 14Aug-14

\begin{tabular}{|c|c|c|c|c|c|c|c|c|c|}
\hline & \multicolumn{3}{|c|}{ DAILY } & \multicolumn{3}{|c|}{ MONTHLY (MTD) } & \multirow{2}{*}{$\begin{array}{l}\text { Laxt month } \\
\text { Blc. (MTD) }\end{array}$} & \multirow{2}{*}{$\begin{array}{l}\text { Cumm. } \\
\text { Balanse }\end{array}$} \\
\hline & & PLAN & ACT & $+1-$ & PLAN & ACT & $+1-$ & & \\
\hline \multirow{4}{*}{ UNE OFF (A) } & EFC-B & 29 & 30 & 1 & 140 & 140 & 0 & -1 & 2 \\
\hline & EFC-C SD & 199 & 199 & 0 & 947 & 950 & 3 & 7 & 30 \\
\hline & EFC-CHB & 73 & 72 & -1 & 346 & 343 & 3 & -6 & 9 \\
\hline & TOTAL & 301 & 301 & 0 & 1433 & 1433 & 0 & 0 & 41 \\
\hline
\end{tabular}

\begin{tabular}{|l|c|c|}
\cline { 2 - 3 } \multicolumn{1}{c|}{} & PLAN & ACTUAL \\
\hline Takt Time & 2.4 & 2.4 \\
\hline DAlLY OT (hr) & 0.0 & 0.0 \\
\hline Eff. & $85.0 \%$ & $97.6 \%$ \\
\hline Line StoP (min) & & 18 \\
\hline isle (min) & 0 & \\
\hline
\end{tabular}

\begin{tabular}{|c|c|c|c|c|c|c|c|c|}
\hline & \multirow{2}{*}{\multicolumn{3}{|c|}{ DAILY }} & \multirow{2}{*}{\multicolumn{3}{|c|}{ MONTHLY (MTD) }} & \multirow{3}{*}{$\begin{array}{l}\text { Laxt month } \\
\text { Blc. (MTD) }\end{array}$} \\
\hline & & & & & & & & \\
\hline & & PLAN & ACT & $+1-$ & PLAN & ACT & $+1-$ & \\
\hline \multirow{4}{*}{ PAINTING (T) } & EFC-B & 29 & 29 & 0 & 140 & 138 & -2 & 4 \\
\hline & EFC-C SD & 199 & 197 & -2 & 946 & 936 & -10 & 23 \\
\hline & EFC-C HB & 73 & 75 & 2 & 347 & 344 & 3 & -12 \\
\hline & TOTAL & 301 & 301 & 0 & 1433 & 1418 & -15 & 15 \\
\hline
\end{tabular}

\begin{tabular}{|l|c|c|}
\cline { 2 - 3 } \multicolumn{1}{c|}{} & PLAN & ACTUAL \\
\hline Takt Time & 2.4 & 2.4 \\
\hline DAlLY OT (hr) & 0.0 & 0.0 \\
\hline Eff. & $85.0 \%$ & $99.6 \%$ \\
\hline Line StoP (min) & & 3 \\
\hline Lble (min) & 0 & \\
\hline
\end{tabular}

\begin{tabular}{|c|c|c|c|c|c|c|c|c|}
\hline & \multicolumn{3}{|c|}{ DAILY } & \multicolumn{3}{|c|}{ MONTHLY (MTD) } & \multirow{2}{*}{$\begin{array}{l}\text { Laxt month } \\
\text { Blc. (MTD) }\end{array}$} \\
\hline & & PLAN & ACT & $+1-$ & PLAN & ACT & $+1-$ & \\
\hline \multirow{4}{*}{ WELDING (W) } & EFC-B & 29 & 30 & 1 & 140 & 141 & 1 & 1 \\
\hline & EFC-C SD & 199 & 199 & 0 & 947 & 948 & 1 & 3 \\
\hline & EFC-C HB & 73 & 72 & -1 & 346 & 346 & 0 & -6 \\
\hline & TOTAL & 301 & 301 & 0 & 1423 & 1435 & 2 & -2 \\
\hline
\end{tabular}

\begin{tabular}{|l|c|c|}
\cline { 2 - 3 } \multicolumn{1}{c|}{} & PLAN & ACTUAL \\
\hline Takt Time & 2.4 & 2.4 \\
\hline DAlLY OT (hr) & 0.0 & 0.0 \\
\hline Eff. & $85.0 \%$ & $98.7 \%$ \\
\hline Line StoP (min) & & 10 \\
\hline blle (min) & 0 & \\
\hline
\end{tabular}

\section{COMMENT : \\ $>$ Highlight Issue : \\ - Standard stock after Line of $26 \quad$ units. \\ Actual stock after Line off : $\quad 26 \quad$ units.}

$>$ Production Problem Information :

[Day shift Problem] :

[Night Shift Problem]

NO SIGNIFICANT PROBLEM

NO SIGNIFICANT PROBLEM

Gambar 3. Contoh Laporan Produksi Harian sesuai Format PCD

\subsection{Analisis Proses Pembuatan Laporan Produksi Harian Saat ini}

Seperti yang ditunjukkan pada Gambar 4 yang merupakan flowchart sebelum perbaikan atau proses saat ini, terdapat enam langkah pemasukan data. Proses input pertama adalah input data unit produksi yang direncanakan dan aktual dari "Sheet Day" to sheet 'KRW Base' ke bagian assembly, delivery, painting, dan welding pada hari itu. Langkah ini sebagai acuan untuk fungsi lain. Kemudian, lembar 'Summary" atau Ringkasan, mengacu pada yang proses input sebelumnya, akan diinput untuk perencanaan dan aktual unit produksi bulanan (kumulatif) dan harian.

Data lain yang harus diinput dari "Sheet Day" ke dalam Lembar Summary adalah rencana dan aktual lembur/overtime, line stop, dan efisiensi dan stock/persediaan. Lembar Summary/Ringkasan adalah laporan yang disampaikan kepada semua departemen dan berisi serta menyimpulkan setiap poin penting. 


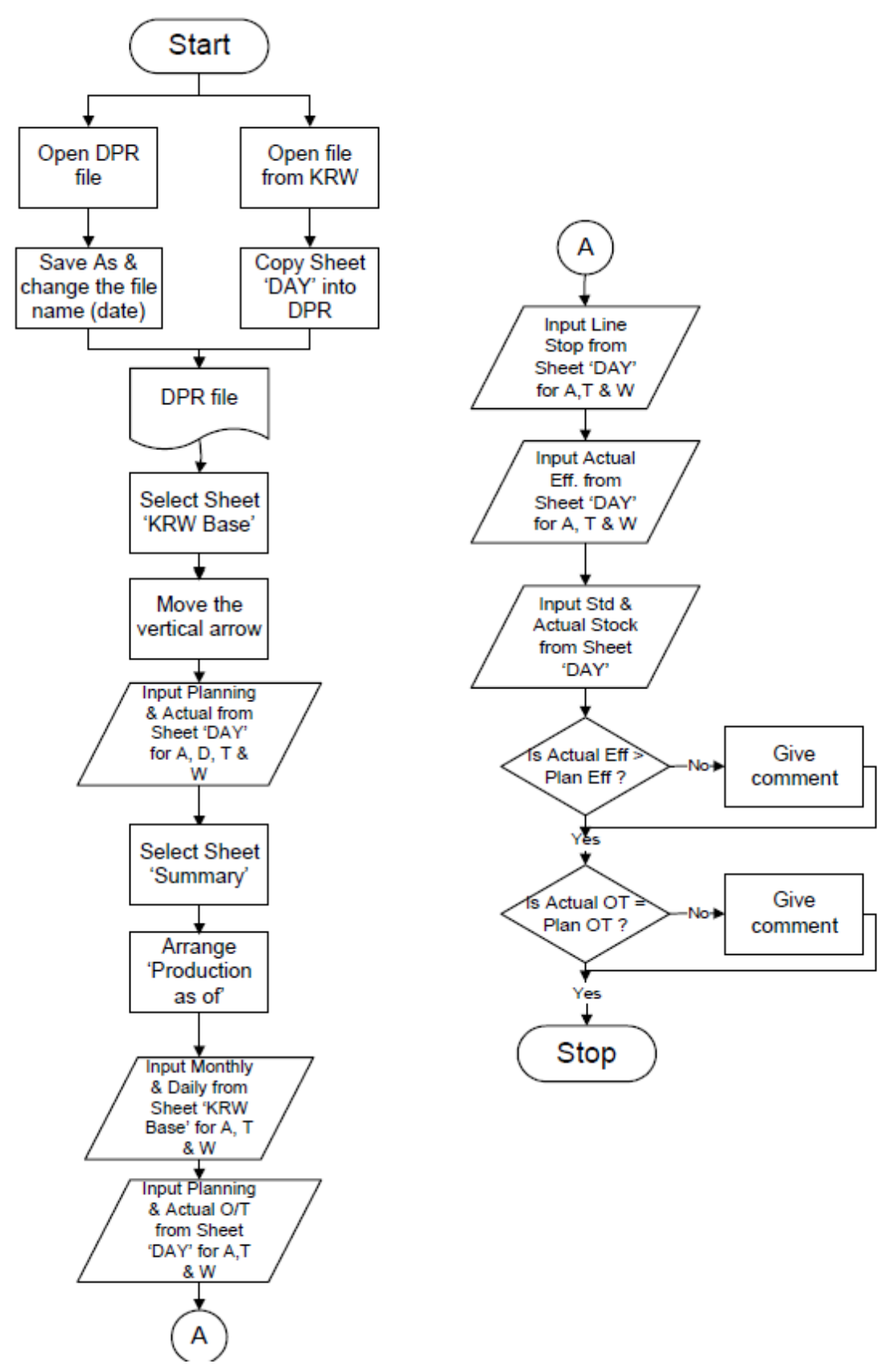

Gambar 4. Diagram Alir Proses Pembuatan Laporan Produksi Harian Saat Ini

Langkah-langkah yang disebutkan sebelumnya menghabiskan waktu pemrosesan lebih tinggi dari proses lainnya. Dalam hal ini, input berarti memindahkan data dengan menyalin nilai dari beberapa sel ke sel yang dituju di lembar yang berbeda. Langkah itu tidak memiliki nilai tambah yang harus dihilangkan untuk mendapatkan proses yang lebih efisien dan efektif.

Berdasarkan hasil pengambilan sampel, waktu rata-rata untuk memproses Laporan Produksi Harian Plant 2 saat ini adalah 11 menit 53 detik, atau dibulatkan menjadi 12 menit. Selain itu, dari hasil pengamatan juga ditemukan kondisi kesalahan saat memproses Laporan Produksi Harian. Hal ini dapat disebabkan oleh berbagai hal seperti implementasi perangkat lunak tidak selalu berjalan lancar, seperti lamanya waktu pemuatan saat membuka file karena datanya kelebihan beban. 


\subsection{Usulan Perbaikan dan Implementasi Perbaikan}

Usulan perbaikan adalah mengembangkan proses pembuatan Laporan Produksi Harian secara otomatis dengan menggunakan Macro-Excel dan VBA. Semua perhitungan dan rumus-rumus yang digunakan akan diprogramkan dengan menggunakan Macro-Excel dan VBA. Tersedia dua buah tombol yang akan digunakan. Tombol pertama berada id lembar/ sheet 'KRW Base', berisi coding untuk melakukan copy dan paste beberapa sel dari Sheet Day, Dialog box mengacu pada nomor kolom yang harus diisi. Selain itu, ditambahkan If-function untuk melakukan double checking, terutama untuk data yang diakumulasikan. Akumulasi dari sheet 'KRW Base' Harus sama dengan kumulatif MTD dari sheet 'DAY' untuk semua proses pada bagian assembly, delivery, painting, dan welding.

Selanjutnya, tombol kedua digunakan untuk menerjemahkan sheet "Summary". Sistem otomatis berjalan berdasarkan tanggal produksi dan sel mengacu pada lembar asli dari sheet "Day". Jika tombol pertama diklik maka akan tampil juga input box yang digunakan untuk mengisi data perencanaan dan aktual produksi yang berupa data unit produksi harian dan bulanan yang diapatkan dari sheet 'KRW Base' yang $\mathrm{n}$ semuanya akan diringkas menjadi sheet "Summary". Demikian pula data lainnya akan diinput, seperti data lembur/overtime, line stop, efisiensi dan stock. Untuk mempermudah pemakai, pada penelitian ini dilakukan penyusunan user manual untuk pembuatan Laporan Produksi Harian.

Setelah dilakukan perbaikan, proses pemasukan data secara manual dihilangkan. Perbedaan dengan sistem saat ini atau sebelum dilakukan perbaikan adalah data harus diinput secara manual pada lembar 'Ringkasan/Summary' yang memiliki banyak data yang harus diisi.

Dimulai dari lembar 'KRW Base' yang sebelumnya memakan waktu lebih lama dalam memasukkan data satu per satu, dengan sistem baru setelah perbaikan, cukup dengan menekan satu tombol, maka datanya otomatis terinputkan. Kemudian, kotak dialog muncul untuk nomor kolom yang wajib diisi. Nomor kolom sesuai dengan tanggal produksi kolom.

Kemudian, sistem akan memeriksa apakah ada perbedaan di antara data 'akumulatif' yang dirumuskan dengan mengisi data dengan yang asli. Jika ada error, itu harus diiperbaiki secara manual. Jika tidak ada error/kesalahan, lanjutkan ke langkah berikutnya. Adapun diagram alir dari proses pembuatan Laporan Produksi Harian setelah perbaikan dapat dilihat pada Gambar 5.

Tabel 2 menyajikan data dari 15 sampel observasi yang diambil secara acak setelah dilakukan perbaikan dan waktu rata-rata pembuatan laporan lebih rendah dari 4 menit. Berdasarkan Tabel 2, dida[atkan penghematan lead time pembuatan Laporan Produksi Harian sebesar sekitar 8 menit (12 menit - 3,66 menit) atau sebesar 66,67 persen.

Tabel 2. Lead Time Pembuatan Laporan Produksi Harian Setelah Perbaikan

\begin{tabular}{|c|c|c|c|c|c|}
\hline Obs & $\begin{array}{c}\text { Waktu } \\
(\text { dtk })\end{array}$ & Obs & $\begin{array}{c}\text { Waktu } \\
(\text { dtk })\end{array}$ & Obs & $\begin{array}{c}\text { Waktu } \\
(\text { dtk })\end{array}$ \\
\hline 1 & 146 & 6 & 225 & 11 & 237 \\
\hline 2 & 213 & 7 & 242 & 12 & 217 \\
\hline 3 & 267 & 8 & 134 & 13 & 236 \\
\hline 4 & 258 & 9 & 268 & 14 & 243 \\
\hline 5 & 199 & 10 & 233 & 15 & 173 \\
\hline \multicolumn{7}{|c|}{ Rata-rata } \\
\hline
\end{tabular}

Berdasarkan pengamatan dan analisis yang dilakukan sebelum dan sesudah perbaikan, dimulai dari diagram alir proses bisnis, dapat dilihat bahwa diagram alir saat ini memiliki banyak bentuk jajaran genjang, yang menunjukkan kegiatan memasukkan data secara manual. Setelah dilakukan observasi, kegiatan tersebut Kegiatan memasukkan data secara manual membutuhkan waktu yang signifikan dan tidak memiliki nilai tambah, sehingga dalam perbaikan aktivitas tersebut berhasil dihilangkan. 


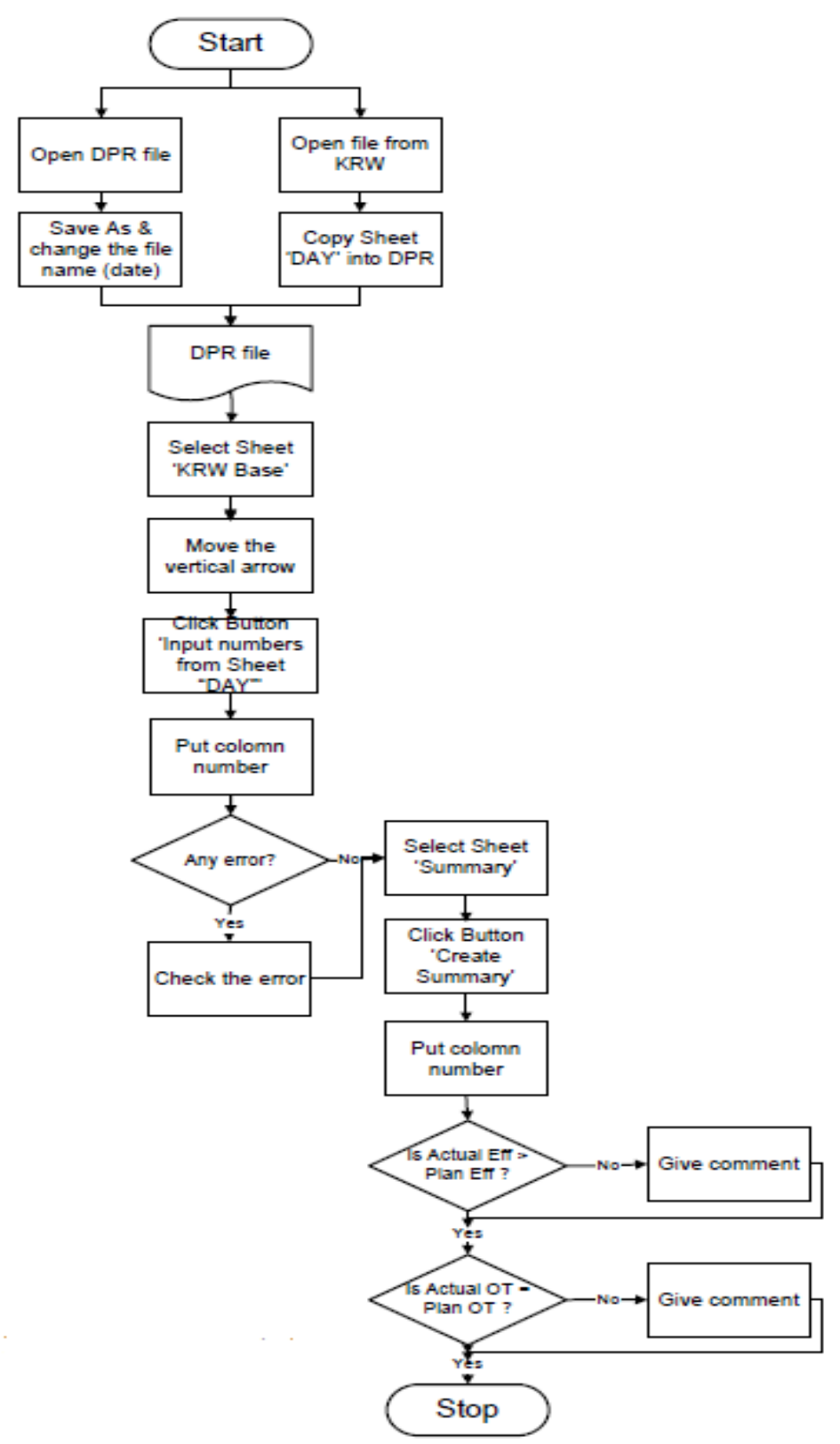

Gambar 5. Diagram Alir Proses Pembuatan Laporan Setelah Perbaikan

\section{Simpulan}

Dalam penelitian ini telah digunakan metodologi perbaikan proses bisnis, Masalah dan tujuan penelitian ini yang telah ditentukan dapat diselesaikan dengan menggunakan Excel macro dan dilakukan perbaikan proses bisnis dalam langkah-langkah pembuatan Laporan Produksi Harian. Dengan dilakukan perbaikan bisnis proses dan penggunakan Excel Macro maka waktu proses pembuatan laporan dapat dikurangi sebesar 67\%. Dari hasil evaluasi didapatkan ketika terjadi perubahan format, mungkin ada satu atau beberapa sel yang tidak bisa diinput secara otomatis. Oleh karena itu, perlu adanya perbaikan untuk menangani masalah itu.

\section{Daftar Pustaka}

1. Aburub, F. (2014). Business process improvement methodology based on business process modelling: Case study from healthcare sector. WEBIST 2014 - Proceedings of the 10th International Conference on Web Information Systems and Technologies, 1(June), 310-317. Retrieved from https://www.researchgate.net/publication/288117928_Business_process_improvement_methodology_b 
ased_on_business_process_modelling_Case_study_from_healthcare_sector

2. Bellgran, M., \& Säfsten, K. (2010). Production Development: Design and Operation of Production Systems. Verlag London: Springer. https://doi.org/10.1016/B978-0-12-800102-8.02001-4

3. Halseth, K. (2018). Process modelling and mapping: The basics. The Guide to the Business Analysis Body of Knowledge (Vol. 2 2). Retrieved from http://c.ymcdn.com/sites/www.bfma.org/resource/resmgr/articles/08_64.pdf

4. Hossain, M. A., Bissenova, A., \& Kim, J. R. (2019). Investigation of wasteful activities using lean methodology: In perspective of kazakhstan's construction industry. Buildings, 9(5). https://doi.org/10.3390/buildings9050113

5. Metzinger, A., \& Latif, N. (2003). Lean manufacturing techniques reduce lead time for implant production. ASEE Annual Conference Proceedings, 323-332. https://doi.org/10.18260/1-2--12531

6. Prasad, Brian Neal, S. (2014). A Flowchart Based Methodology for Process Improvement. Quality Concepts'93 World Class Manufacturing Proceedings, (October 1993), 53-74. https://doi.org/10.13140/RG.2.1.2559.4327

7. Rashid, O. A., \& Ahmad, M. N. (2013). Business Process Improvement Methodologies: An Overview. Journal of Information System Research Innovation, 5, 45-53. Retrieved from http://seminar.utmspace.edu.my/jisri/

8. Srinivasan K A, R., \& Shrehari J, J. (2017). Applied Procedures for Lead Time Reduction: A Review. International Journal of Engineering Trends and Technology, 43(3), 169-172. https://doi.org/10.14445/22315381/ijett-v43p228 